\title{
SMART
}

SMART

(Journal of English Language Teaching and Applied Linguistics)

Volume 7, No. 1, January 2021 Page. 27-34

p-ISSN: 2356-2048 e-ISSN: 2356-203x

\section{IMPROVING THE ENTREPRENEURIAL SPIRIT IN THE FIELD OF TRANSLATION SERVICES FOR ENGLISH EDUCATION STUDENTS}

\author{
Suroyo \\ STIE Tribuana, Postgraduated of Management \\ Email Correspondence: suroyo@stietribuana.ac.id
}

\begin{abstract}
This study aims to improve entrepreneurial attitudes and behavior in the field of translation services for students of English education research programs through internships. The research method was a comparative theoretical analysis related to the development of translation services and business development for students studying several librarians. The results of the study indicated that entrepreneurship was a process, traits, and traits that have a strong will to bring innovative ideas into real-world businesses and are able to develop.
\end{abstract}

Keyword: Entrepreneur, Translation Services, Internship

\section{INTRODUCTION}

The manpower issue is one of the problems in Indonesia nowadays. However, it does not necessarily become a problem in this country. Numerous aspects support to overcome these problems, including the role of universities. It is because universities have become one of the aspects that encourage the progress of the nation. The higher education institution does not directly appear to be responsible for this country but responsible for related problems. Indonesia's economic growth is quite fast, reaching 5.02\% in the first quarter of 2019. Based on current economic growth, it should be easy for society to obtain work.

The problem of natural resources in Indonesia that has not been resolved optimally has reached 250 million. It is an important condition for overcoming economic problems. One of the issues the government has proclaimed to reduce

Creation is distributed under the Creative Commons License Attribution 


\section{Suroyo...}

job shortages is through entrepreneurship. Through entrepreneurship, society is no longer looking for work but creating jobs. By this government program, universities must also support the program and must participate in improving students' entrepreneurial abilities. Bygrave (1994) in Alma, B. (2007) defined entrepreneur " $\ldots$ as the person who destroys the existing economic order by introducing new products and services, by creating new forms of organization, or by exploring new raw materials"

Entrepreneurship is used as a subject for college courses and extracurricular activities for students. It is planned because the graduates or students who are still active in higher education can apply entrepreneurial concepts and skills. Hence, there is no need to wait for companies to accept job applications or even to become civil servants. Based on research conducted by Sukirman (2017) concerning "Jiwa Kewirausahaan dan Nilai Kewirausahaan Meningkatkan Kemandirian Usaha melalui Perilaku Kewirausahaan", it was revealed that the strengthening of entrepreneurial spirit will have an impact on strengthening entrepreneurial behavior. Also, increasing entrepreneurial values will increase entrepreneurial behavior. Increasing entrepreneurial spirit can increase the formation of business independence but it cannot be achieved immediately. It means that small business actors who can increase the entrepreneurial spirit will not automatically establish business independence. Thus, even though Sukirman's research has a similar topic with this research, this study will examine more deeply the spirit of entrepreneurship through an entrepreneurial program.

However, in the implementation process, students, especially students of English education study programs, still face difficulties and are still confused about choosing the type of entrepreneurship to work in according to their field. They still believe that the type of business that is suitable for their field is only business equipment, or that the private sector does not need them. Starting from this idea, as an entrepreneurship lecturer in the English Education Study Program, the writer attempted to search for solutions by developing and improving their 


\section{Improving...}

entrepreneurial potential Hence, students can open themselves up that there are abundant opportunities in the field of English to become entrepreneurs. Therefore, in this study, the writer attempted to take the entrepreneurial potential of English, especially in the courses available in the curriculum, i.e., translation. The essence expression of the language translator is simply the term of someone who speaks one language and can transliterate it in another. The translation is the process of interpreting and conveying messages in different language environments. Brislin (1976) elucidated that "Translation in the general term is referring to the transfer of thought and ideas from one language (source) to another (target), whether the language is in written or oral form; whether the languages have established orthographies or do not have such standardization or whether one or both languages is based on signs, as with sign language of the deaf".

Entrepreneurship development in translation services refers to the process of creating new things with the time and effort required, taking financial, physical, and accompanying risks, overcoming imbalances in the money obtained, having personal benefits when operating translation services, and contentment and freedom. Entrepreneurship is catching opportunities, by taking advantage of opportunities to open and run new or innovative businesses. Therefore, hosting companies can become bigger and more independent in facing competitive challenges (Nasrullah Yusuf, "Konsep Dasar Kewirausahaan”). Entrepreneurship is an attitude, perspective, or spirit of innovative, and independent innovation. Although they have to face risks, they can also create new businesses by taking advantage of existing opportunities. Students really need the concept of entrepreneurship as a provision for their life to be able to overcome challenges in life and survive. Therefore, it is crucial to trigger the students to always be creative in using existing opportunities for creating innovation.

The aim of developing entrepreneurship by utilizing translating services through internship is to explore entrepreneurial potential contained in entrepreneurship courses. This course not only provides lectures in the classroom 


\section{Suroyo...}

but also takes part in an internship in places that have been designated by the Study Program.

Through the Translation Entrepreneurial Internship Program, students can develop entrepreneurial potential in translation practices, translation problems, how to solve these problems, and the relationship between translation and local culture. The translation entrepreneur internship does not only equip students with theoretical knowledge but also insight regarding translation practices in companies, printing companies, and various mass media organizations.

\section{RESEARCH METHOD}

This research was qualitative research with exploratory research methods. By using this method, the researcher attempted to explore all the possibilities to answer the research problem. This research is completed in several stages by directing the research problem concerning the object of research. Researchers collected the data from observations, interview informants, collect files, and visual data. From these observations, information was obtained related to who could be used as informants. Respondents who were used as this research topic comprised of four lecturers in translation courses, two translation, two publishers and printing, and one print and audio-visual media.

\section{RESULTS AND DISCUSSION \\ Potential of Translation Entrepreneurial Field}

Based on observations in the entrepreneurship class and data collected from interviews with information providers, it is identified that all informants agreed that the translation field has great entrepreneurial potential. From the observations of the translation class, it can be observed that in fact most of the students in the entrepreneurship class had the potential for translation. However, they did not obtain the details yet on how to join the field of professional translation and how to obtain entrepreneurial training and insight in the field of translation. Based on 


\section{Improving...}

observations in entrepreneurship class and data collected from interviews with the informants, they concurred that the translation has great entrepreneurial potential.

In a translation course, translation exercises were mostly sufficient to translate various translation genres, such as formal translations, popular articles, brochures, manual machines, etc. However, there was not enough insight regarding how to follow up on translation skills as an entrepreneurial career. There was no sufficient knowledge to understand how to start a business in the field of translation, take advantage of student potential, build networks, and build an entrepreneurial mindset.

Specific majors identified in this research were job opportunities or entrepreneurship in the field of translation, including translators, interpreters, film translators, translation service bureaus, etc.

\section{Translation Learning Model}

Based on the evaluation results of translation learning activities, it is recognized that the results of translation learning were only limited to theoretical abilities related to translation theory and translation skills. At the same time, the output as a translation entrepreneur has not been realized. Therefore, the results of this study developed alternative translation learning methods that can adapt translation students to the needs of freelance translation. Even though they have not graduated from higher education or college, they can continue to be involved in freelance translation. Through this research, a method was proposed to support students to gain more than mastering theoretical skills and translation skills. Moreover, students can also master one or more of the translation tools used. Thus, they can complete translation and comprehend the real world of professional translation through this internship program.

Based on the results of the student interview, it was obtained the following information:

Students required three credits in translation courses. In this subject, translation theory and translation practice were taught. After obtaining translation 


\section{Suroyo...}

theory (such as procedures, strategies, translation skills, etc.), students would receive translation training for various types of texts. The translation results would be discussed in class, or could only be corrected and commented on by the lecturer. The data obtained from the students showed that entrepreneurship was rarely given, even professional translation circles or translation circles. Only four students $(17 \%)$ provided the information they had heard about the experiences of lecturers in translation work. In terms of ability, $87 \%$ of students felt less confident in their translation skills because they believed that the translation results were still low.

Meanwhile, the results of interviews conducted by translation lecturers showed that the material provided only involved translation theory and practice as well as translation skills. Due to the semester credit system implemented, entrepreneurship-related materials had not been provided. A suggestion for lecturers to address this problem was to increase the time allocated for translation courses. The lecturers provided possible opportunities to the students for translation internships or business publications. Students should also be given specific material about the various tools available for translators to make the translation process more effective.

Based on the results of interviews and observations of the learning conditions and the world of translation, as well as the literature review of the world of translation, research models or methods of translation learning are as follows.

In terms of courses, it needs to be an additional time allocation in the semester credit system for translation courses. This additional time is to provide more material on the tools to assist and speed up the translation. This course also requires an internship as another type of lecture. Translation internship courses can be carried out in business translation, publication/printing. Internships in this course do not always have to live or work in a company because translation work can be done anywhere, including at home, campus, or any other possible place. 


\section{Improving...}

The advantage of this internship program is that students can explore and practice their translation skills and gain experience in the professional translation field. Another benefit is that the internship provides a professional translators network.

In terms of lecture materials, it is necessary to provide material on information and communication technology (ICT) equipment that supports current translation work. In essence, ICT tools can increase the translation efficiency of translators. Through the analysis above, language can guide the learning of translation courses. Students not only master translation theory, skills, and practice but also guide entrepreneurial skills. The recommendations of this research result will only add to the existing translation learning model. The prerequisites for translation to take a translation course must be met for the smooth running of the translation course. The translation course itself can be divided into several courses. Total credits for translation courses are between 10 and 12 credits. Translation courses include translation theory and practice. During the internship, students are required to complete at least one translation project provided by the company where the internship project is located. It is expected that after the internship, students will have the courage to set up their own translation business individually or in groups.

\section{CONCLUSION}

From a financial and business sustainability perspective, entrepreneurship in the field of language translation is a very promising career. In the era of globalization, the penetration of one culture to another is unlimited and one cannot choose. Of course, this situation requires multiple translators, who can bridge different cultures and languages. Of course, foreign companies entering Indonesia also need a translation. Books, information on the Internet, and collaboration between institutions in multiple languages require translation. The needs in translation have created entrepreneurial potential in the field of translation. It causes translation professions are very diverse. 


\section{Suroyo...}

Higher education is responsible for educating the youth. It must be able to contribute to the progress of the nation which improves the welfare of the Indonesian society. Higher education must be able to produce entrepreneurs who support the national economy. The language field, particularly the field of translation, makes it possible to use the methods or models proposed in this study to train entrepreneurs in the field of translation.

\section{REFERENCES}

Bygrave, W. D. (1997). The Portable MBA in Entrepreneurship. New York: John Willeys \&Son Inc.

Brislin, R. W. (1976). Translation: Application and Research. New York: Gradner Press Inc.

Sukirman, S. (2017). Jiwa Kewirausahaan dan Nilai Kewirausahaan Meningkatkan Kemandirian Usaha melalui Perilaku Kewirausahaan. Jurnal Ekonomi Dan Bisnis, 20(1), 113-131.

Yusuf, N. (2006). Wirausaha dan Usaha Kecil. Jakarta: Modul PTKPNF Depdiknas. 